\title{
Evidence for a Weak Active External Adsorption of Azospirillum brasilense Cd to Wheat Roots
}

\author{
By YOAV BASHAN, ${ }^{*}$ HANNA LEVANONY ${ }^{1}$ AND EUGENIA KLEIN ${ }^{2}$ \\ Department of Plant Genetics ${ }^{1}$ and Electron Microscopy Unit, Department of Biological \\ Services $^{2}$, The Weizmann Institute of Science, Rehovot 76100, Israel
}

(Received 17 April 1986)

\begin{abstract}
Azospirillum brasilense Cd, when inoculated onto wheat roots, multiplied and formed aggregates on the root surfaces and established an internal root population. Washing the roots removed most of the external but not the internal bacterial population. Killing the bacteria before or after their interaction with the roots eliminated the adsorbed bacteria from the root surface. The external adsorption of $A$. brasilense to wheat roots can be categorized as a weak active process.
\end{abstract}

\section{INTRODUCTION}

There has been intensive study during the last decade on interactions between the rhizosphere bacterium Azospirillum and various cereals, particularly regarding the potential contribution to plant growth and yield (Bashan, 1986a; Okon, 1985). Azospirillum spp. are known to colonize roots of many cereals and to affect plant metabolism (Döbereiner \& Baldani, 1979; Baldani et al., 1983; Kapulnik et al., 1981; Okon \& Kapulnik, 1986). The mechanism involved in this adsorption is unknown (Patriquin \& Döbereiner, 1978; Patriquin et al., 1983; Schank et al., 1979, 1983; Umali-Garcia et al., 1980). Gafni et al. (1986) described various modes of adsorption of $A$. brasilense to maize roots and Jain \& Patriquin (1984) reported differences between various strains of Azospirillum in the degree of attachment to wheat root-hairs.

The purposes of the present study were to estimate the strength of the association between $A$. brasilense and wheat roots and to find out whether active metabolism of the participants is involved.

\section{METHODS}

Organisms and growth conditions. Azospirillum brasilense Cd (ATCC 29710) was cultured on nutrient broth (Difco) medium, as previously described (Bashan \& Levanony, 1985). Bacteria were inoculated into 3-d-old wheat seedlings (Triticum aestivum cv. 'Deganit') grown on wet filter paper in Petri dishes (five seedlings per plate). Bashan (1986b) demonstrated a marked effect of inoculation on wheat seedlings at this growth stage. Inoculation was performed by placing $2 \mathrm{ml}$ double-washed bacterial suspension in phosphate-buffered saline (PBS) pH 7.2 $\left(5 \times 10^{8}\right.$ c.f.u. $\left.\mathrm{ml}^{-1}\right)$ directly on the roots. All experiments were conducted in a growth chamber (Conviron model EF7H, Controlled Environment, Canada) at $22 \pm 2{ }^{\circ} \mathrm{C} .10 \mathrm{~h}$ light and $14 \mathrm{~h}$ darkness.

$A$. brasilense Cd was identified and enumerated by the indirect and competition enzyme-linked immunosorbent assay (ELISA) developed for the detection of this strain. In the indirect ELISA, 3-4 mm pieces of roots from each plant were placed in $0.15 \mathrm{ml}$ coating buffer in one well. In the competition ELISA, roots of 15 inoculated seedlings (per replicate) were homogenized with a glass homogenizer (Kontes, USA), centrifuged at $12000 \mathrm{~g}$ for $10 \mathrm{~min}$ and the pellet was suspended in $2 \mathrm{ml} \mathrm{PBS}$ and used as a competitor. The rest of the ELISA procedure was as described elsewhere (Levanony et al., 1987). Bacterial counts were also verified by the plate count method on BL semiselective medium (Bashan \& Levanony, 1985).

Treatment of bacteria and roots. Forty-eight hours after inoculation roots of 25 seedlings per treatment were treated as follows: (i) rinsed gently for $10 \mathrm{~s}$ in tap water in a 1 litre container with slow stirring; (ii) washed in the same way for $2 \mathrm{~min}$; (iii) soaked for $30 \mathrm{~min}$ in tap water and then washed for $2 \mathrm{~min}$ as described above. Other roots were surface disinfected with $1 \%(\mathrm{v} / \mathrm{v}) \mathrm{NaOCl}$ for $3 \mathrm{~min}$ and washed for $2 \mathrm{~min}$ in tap water.

In an additional experiment, roots of inoculated seedlings were placed in $15 \mathrm{ml}$ tubes (three seedlings per tube) and rinsed with $10 \mathrm{ml}$ sterile PBS pH 7.2. The PBS was replaced three times with a Pasteur pipette, then the 
seedlings were agitated in a vortex mixer (Vortex-Genie, Scientific Industries) at 1800 r.p.m. for 60 s. The roots were then rinsed twice with PBS and the number of $A$. brasilense $\mathrm{Cd}$ was determined in root homogenates by competition ELISA, and on the surface of root segments by indirect ELISA. Roots were concomitantly homogenized with a sterile glass homogenizer and decimally diluted in PBS; $0.1 \mathrm{ml}$ samples were spread on semiselective BL medium for plate counts (Bashan \& Levanony, 1985).

To evaluate the involvement of metabolic activities in root-bacteria interactions, either bacteria or roots or both were treated by $\gamma$-irradiation ( $25 \mathrm{kGy}$ from a ${ }^{60} \mathrm{Co}$ source). This irradiation killed all bacterial cells, both in the suspension, and in plant roots as tested by bacterial counts of root homogenates on BL semi-selective medium. Plant root cells were also killed by this treatment. Inoculation with dead bacterial culture (equivalent before sterilization to $10^{8}$ c.f.u. $\mathrm{ml}^{-1}$ ) or inoculation onto dead roots (killed by $\gamma$-irradiation) was done as previously described for live bacteria. In addition, roots inoculated with live bacteria were sterilized $48 \mathrm{~h}$ later by $\gamma$ irradiation and washed for $10 \mathrm{~s}$, as previously described. Controls used in these experiments were: inoculated roots, uninoculated washed or unwashed roots, uninoculated disinfected roots and dead roots.

Scanning electron microscopy (SEM). Roots were fixed for $5 \mathrm{~h}$ in $5 \%(\mathrm{v} / \mathrm{v})$ glutaraldehyde solution in $0.2 \mathrm{M}-$ cacodylate buffer $\mathrm{pH} 7 \cdot 2$, washed twice in the same buffer and then dehydrated with ethanol, $50 \%$ (v/v) for $30 \mathrm{~min}, 70 \%$ for $10 \mathrm{~h}, 100 \%$ for $30 \mathrm{~min}$, and $100 \%$ for $60 \mathrm{~min}$ (all this was done at $4{ }^{\circ} \mathrm{C}$ ). The samples were dried in a critical point dryer (Tousimis, USA) in freon, then in $\mathrm{CO}_{2}$. The dried samples were stuck to stubs, coated with gold and examined by a Philips SEM505 scanning electron microscope at 20-30 kV.

Experimental design. All experiments were repeated three times with five replicates each. A replicate consisted of either five seedlings, six microtitre plate wells, five SEM stubs or five Petri dishes. The results presented are from representative experiments.

\section{RESULTS AND DISCUSSION}

By using the ELISA technique for the specific detection of $A$. brasilense $\mathrm{Cd}$ it was possible to detect a relatively large number of the associated bacteria in wheat roots. Two different types of $A$. brasilense populations were detected: an external one on the root surface and an internal one in the cortex.

The external population showed an aggregate mode of colonization and the bacteria were connected to each other and to the root surface by fibrillar material (Fig. $1 a-c$ ). Slight rinsing of the roots released $70 \%$ of this population (Table 1), as found for maize roots (Gafni et al., 1986). The external population decreased to a very low level (less than $10^{4}$ cells per $\mathrm{g}$ roots, which is below the sensitivity of the ELISA technique) with longer washing (Fig. 1d, Table 1). (The plate count method was not used because it would reveal both the internal and the external populations.) Inoculated wheat roots agitated by vortex mixing released most of the externally adsorbed bacteria; the bacteria detected by competition ELISA in the root homogenates were

Table 1. Number of $A$. brasilense $C d$ adsorbed to wheat root surfaces following different methods of root washings (measured $48 \mathrm{~h}$ after inoculation)

Root washing method

(a) Not washed

(b) Rinsed for $10 \mathrm{~s}$ with slow stirring

(c) Washed for 2 min with slow stirring

(d) Soaked for $30 \mathrm{~min}$ then washed as in (c)

(e) Rinsed as in (b) then vortex mixed for $60 \mathrm{~s}$
No. of bacteria

Bacterial on root surfaces inoculation* per $g$ roots $\dagger$

$\begin{array}{cc}+ & 1 \pm 0.3 \times 10^{5} \\ - & 0 \\ + & 3 \pm 0.6 \times 10^{4} \\ + & 0 \\ - & 0 \\ + & 0 \\ + & 4 \pm 0.4 \times 10^{6} \ddagger \\ + & 0 \S\end{array}$

* With $10^{8}$ c.f.u. $\mathrm{ml}^{-1}, 2 \mathrm{ml}$ per plate.

$\dagger$ Measured by indirect ELISA. Zero represents bacterial numbers below the sensitivity of the method $\left(<10^{4}\right.$ per $g$ roots).

I Inside the roots after root homogenization, measured by competition ELISA.

$\S$ On the root surface. 

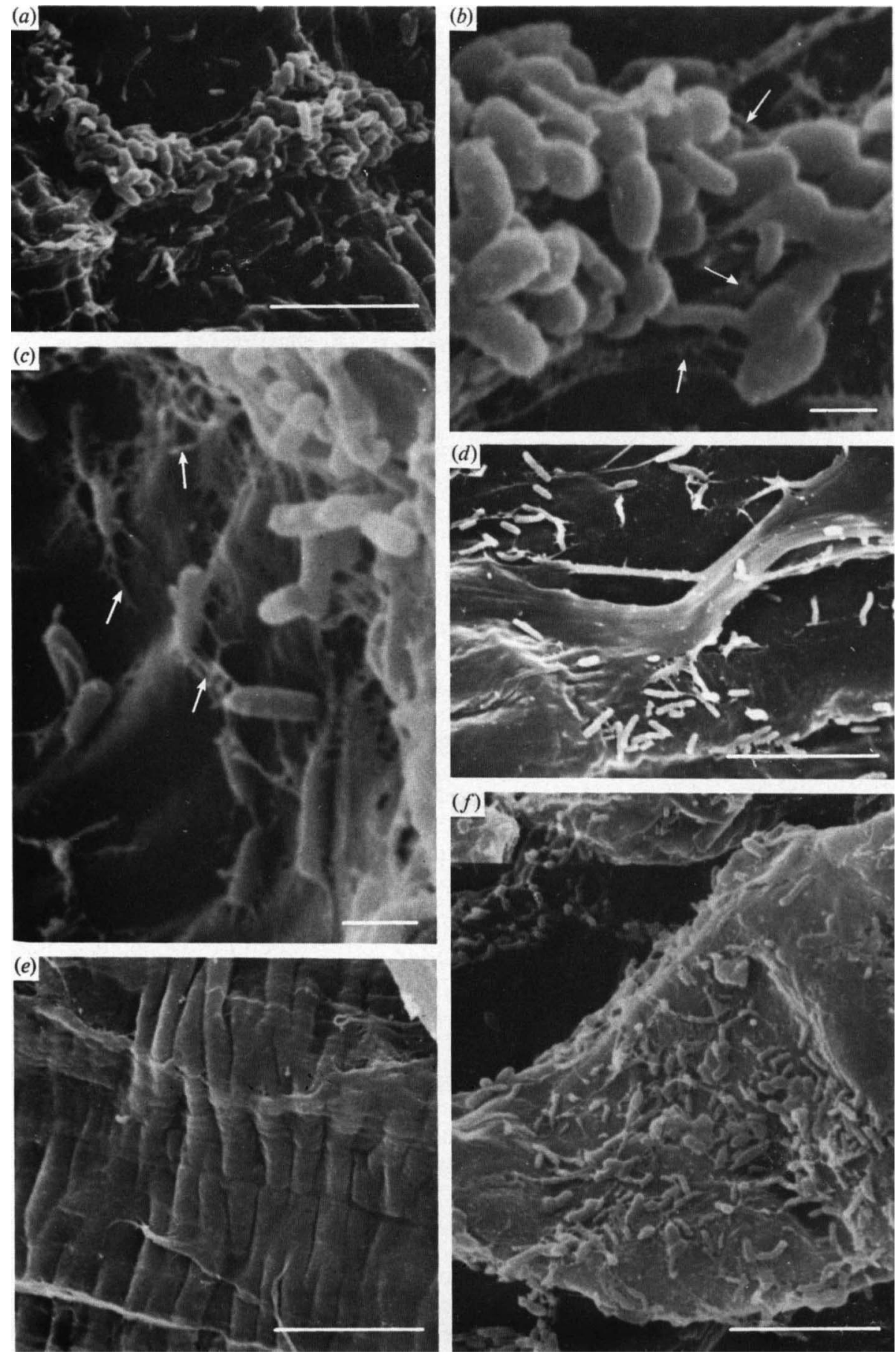

Fig. 1. Scanning electron micrographs of wheat roots inoculated with $A$. brasilense Cd. The bars represent $10 \mu \mathrm{m}$ in $(a),(d),(e)$ and $(f)$, and $1 \mu \mathrm{m}$ in $(b)$ and $(c) .(a)$ Bacterial aggregates at the border between the elongation zone and root hair zone. (b) Higher magnification of the aggregate in $(a)$ showing fibrillar material (arrows) connecting the bacteria to each other. $(c) A$. brasilense cells connected to the root surface by fibrillar material (arrows). (d) Random distribution of bacterial cells after very light washing; there are no bacterial aggregates. $(e)$ Wheat root after light surface disinfection with $1 \% \mathrm{NaOCl}$. $(f)$ Bacterial colonization on dead root-tip cell. 
Table 2. Adsorption of $A$. brasilense $C d$ to wheat roots (measured $3 d$ after inoculation)

\begin{tabular}{|c|c|c|c|}
\hline \multirow[b]{2}{*}{ Root treatment* } & \multirow{2}{*}{$\begin{array}{c}\text { Bacterial } \\
\text { inoculation } †\end{array}$} & \multicolumn{2}{|c|}{ No. of bacteria per $g$ roots } \\
\hline & & Competition ELISA & Counts on BL medium \\
\hline None & $\begin{array}{l}\text { Live } \\
\text { Dead } \ddagger\end{array}$ & $\begin{array}{c}1 \pm \underset{0}{0.2} \times 10^{7} \\
0\end{array}$ & $\begin{array}{c}1.3 \pm 0.4 \times 10^{7} \\
0\end{array}$ \\
\hline Dead $\ddagger$ & $\begin{array}{l}\text { Live } \\
\text { Dead }\end{array}$ & $\begin{array}{c}4 \pm 0.4 \times 10^{7} \\
0\end{array}$ & $\begin{array}{c}2.8 \pm 0.3 \times 10^{7} \\
0\end{array}$ \\
\hline Sterilized $\ddagger$ after inoculation & Live & 0 & 0 \\
\hline Disinfected $\S$ after inoculation & Live & $2 \pm 0.4 \times 10^{4}$ & $8.4 \pm 1.6 \times 10^{4}$ \\
\hline Disinfected $\S$ & None & 0 & 0 \\
\hline $\begin{array}{l}\text { * All ro } \\
+ \text { With } \\
\ddagger \text { Expo } \\
\S \text { Disin }\end{array}$ & $\begin{array}{l}\text { washed for } 10 \\
\mathrm{ml}^{-1}, 2 \mathrm{ml} \mathrm{pe} \\
\text { radiation }(25 \\
3 \mathrm{~min} \text { in } 1 \%\end{array}$ & $\begin{array}{l}\text { h slow stirring, after } \\
\text {, or with equivalent }\end{array}$ & $\begin{array}{l}\text { t treatment. } \\
\text { d bacteria. }\end{array}$ \\
\hline
\end{tabular}

probably those which had penetrated into the inner root layers (Patriquin \& Döbereiner, 1978). This internal population was relatively large: $10^{6}-10^{7}$ c.f.u. per g root.

Disinfection of highly colonized roots eliminated most of the bacteria (only $0.2 \%$ of the original population remained alive) (Fig. 1e, Table 2). When these roots were aseptically placed on a semi-selective BL medium only a few colonies grew around them. Application of killed bacterial cells either to live or to dead roots resulted in negligible external adsorption. However, killing the roots before inoculation had no effect on the degree of bacterial adsorption (Fig. $1 f$, Table 2). $\gamma$-Irradiation following a massive root colonization of $A$. brasilense $\mathrm{Cd}$ killed both the bacteria and the plant and resulted in elimination of most of the dead bacterial cells from the roots. If dead bacteria were still attached to the roots they could be enumerated by the ELISA technique, which is capable of detecting both dead and live bacteria (Levanony et al., 1987). Similarly, elimination of most of the bacterial cells after killing colonized roots could not be attributed to the light rinsing used in this procedure, because such treatment did not eliminate live bacteria from roots, as indicated above.

Adsorption of bacteria to a solid phase is known (Fletcher et al., 1980) and may give the rhizosphere bacteria nutritional and favourable microspace advantages. Rhizosphere bacteria may adsorb as single cells or as aggregates, but usually are not scattered randomly (Dazzo \& Hollingsworth, 1984; Shimshick \& Hebert, 1979). Azospirillum cells were found in the intercellular spaces of the cortex of various cereals, grown either axenically (Berg et al., 1979; Patriquin \& Döbereiner, 1978) or under field and greenhouse conditions (Bashan, 1986a; Schank et al., 1979), as well as within dead cortex cells and root hairs (Jain \& Patriquin, 1984; Patriquin \& Döbereiner, 1978).

This study reveals that the external adsorption of $A$. brasilense to wheat roots is rather weak: light washing removed most of the aggregates, and more prolonged washing removed nearly all the bacterial cells present on the root surface. These findings differ from those obtained for some rhizobia-legume interactions (Dazzo \& Hollingsworth, 1984) and for the Azospirillum-maize interaction (Gafni et al., 1986).

Adsorption of bacteria to plant roots can be either passive or it may depend on the active metabolism of both organisms (Fletcher et al., 1980; Shimshick \& Hebert, 1979). This work demonstrated that killing the bacteria, either before or after adsorption, prevented this process almost completely, indicating that active metabolism of the Azospirillum cells was essential for the association with the roots. Since these bacteria could colonize and adsorb to dead roots, the active metabolism of the plant may be less important. The adsorption of $A$. brasilense to the surfaces of wheat roots can thus be categorized as a weak metabolism-dependent process.

This paper was written in memory of the late Mr Avner Bashan. We thank Professor M. Feldman from our department for helpful suggestions, Miss Einat Carmi for technical assistance and Mr Y. Avivi for criticism of the manuscript. This study was partially supported by an Eshkol fellowship from the Ministry of Science and Development, Israel, to the senior author. 


\section{REFERENCES}

Baldani, V. L. D., Baldani, J. I. \& Döbereiner, J. (1983). Effects of Azospirillum inoculation on root infection and nitrogen incorporation in wheat. Canadian Journal of Microbiology 29, 924-929.

BASHAN, Y. (1986a). Enhancement of wheat root colonization and plant development by Azospirillum brasilense $\mathrm{Cd}$. following temporary depression of the rhizosphere microflora. Applied and Environmental Microbiology 51, 1067-1071.

BASHAN, Y. $(1986 b)$. Significance of timing and level of inoculation with rhizosphere bacteria on wheat plants. Soil Biology and Biochemistry 18, 297-301.

BASHAN, Y. \& LEVANONY, H. (1985). An improved selection technique and medium for the isolation and enumeration of Azospirillum brasilense. Canadian Journal of Microbiology 31, 947-952.

BerG, R. H., Vasil, V. \& VASIL, I. K. (1979). The biology of Azospirillum-sugarcane association. II. Ultrastructure. Protoplasma 101, 143-163.

Dazzo, F. B. \& Hollingsworth, R. E. (1984). Trifoliin A and carbohydrate receptors as mediators of cellular recognition in Rhizobium trifolii clover symbiosis. Biology of the Cell 51, 267-274.

Döbereiner, J. \& Baldani, V. L. D. (1979). Selective infection of maize roots by streptomycin-resistant Azospirillum lipoferum and other bacteria. Canadian Journal of Microbiology 25, 1264-1269.

Fletcher, M., LathaM, M. J., LYNCH, J. M. \& RUTTER, P. R. (1980). The characteristics of interfaces and their role in microbial attachment. In Microbial Attachment to Surfaces, pp. 67-78. Edited by R. C. W. Berkeley, J. M. Lynch, J. Melling, P. R. Rutter \& B. Vincent. Chichester: Ellis Horwood.

GafNI, R., OKon, Y., Kapulnik, Y. \& Fischer, M. (1986). Adsorption of Azospirillum brasilense to corn (Zea mays) roots. Soil Biology and Biochemistry 18, 69-76.

Jain, D. K. \& Patriquin, D. G. (1984). Root hair deformation, bacterial attachment, and plant growth in wheat-Azospirillum associations. Applied and Environmental Microbiology 48, 1208-1213.
KaPulnik, Y., OKon, Y., Kigel, J., NuR, I. \& Henis, Y. (1981). Effects of temperature, nitrogen fertilization, and plant age on nitrogen fixation by Setaria italica inoculated with Azospirillum brasilense (strain Cd). Plant Physiology 68, 340-343.

LeVanoNy, H., BashaN, Y. \& KaHANA, Z. E. (1987). Enzyme-linked immunosorbent assay for specific identification and enumeration of Azospirillum brasilense Cd. in cereal roots. Applied and Environmental Microbiology 5 (in the Press).

OxON, Y. (1985). Azospirillum as a potential inoculant for agriculture. Trends in Biotechnology 3, 223-228.

OKON, Y. \& KAPULNIK, Y. (1986). Development and function of Azospirillum-inoculated roots. Plant and Soil 90, 3-16.

Patriquin, D. G. \& Döbereiner, J. (1978). Light microscopy observations of tetrazolium-reducing bacteria in the endorhizosphere of maize and other grasses in Brazil. Canadian Journal of Microbiology 24, 734-742.

Patriquin, D. G., Döbereiner, J. \& JaIN, D. K. (1983). Sites and processes of association between diazotrophs and grasses. Canadian Journal of Microbiology 29, 900-915.

Schank, S. C., SMith, R. L., Weiser, G. C., Zuberer, D. A., BOUTON, J. H., QuESENBERRY, K. H., TYLER, M. E., Milam, J. R. \& Littell, R. C. (1979). Fluorescent antibody technique to identify Azospirillum brasilense associated with roots of grasses. Soil Biology and Biochemistry 11, 287-295.

SChaNK, S. C., SMith, R. L. \& LitTell, R. C. (1983). Establishment of associative $\mathrm{N}_{2}$-fixing systems. Proceedings of the Soil and Crop Science Society of Florida 42, 113-117.

Shimshick, E. J. \& HeberT, R. R. (1979). Binding characteristics of $\mathrm{N}_{2}$-fixing bacteria to cereal roots. Applied and Environmental Microbiology 38, 447-453.

Umali-Garcia, M., Hubbell, D. H., Gaskins, M. H. \& DAzzo, F. B. (1980). Association of Azospirillum with grass roots. Applied and Environmental Microbiology 39, 219-226. 